\title{
Southern Chile, trout and salmon country: invasion patterns and threats for native species
}

\author{
Sur de Chile, país de truchas y salmones: patrones de invasión y amenazas \\ para las especies nativas
}

\begin{abstract}
DORIS SOTO ${ }^{1,2, *}$, IVÁN ARISMENDI ${ }^{1}$, JORGE GONZÁLEZ ${ }^{1}$, JOSÉ SANZANA ${ }^{1}$, FERNANDO JARA ${ }^{3}$, CARLOS JARA $^{4}$, ERWIN GUZMAN ${ }^{1}$ \& ANTONIO LARA ${ }^{5}$
\end{abstract}

\author{
${ }^{1}$ Núcleo Milenio FORECOS, Laboratorio Ecología Acuática, Instituto de Acuicultura, Universidad Austral de Chile, \\ Casilla 1327, Puerto Montt, Chile \\ ${ }^{2}$ Present address: Inland Water Resources and Aquaculture Service (FIRI), Fisheries Department, FAO of UN, Via delle \\ Terme di Caracalla, 00100, Rome, Italy \\ ${ }^{3}$ Universidad San Sebastián, Casilla 40-D, Puerto Montt, Chile \\ ${ }^{4}$ Instituto de Zoología, Universidad Austral de Chile, Casilla 653, Valdivia, Chile \\ ${ }^{5}$ Núcleo Milenio FORECOS, Instituto de Silvicultura, Universidad Austral de Chile, Casilla 653, Valdivia, Chile; \\ *Corresponding author: doris.soto@fao.org
}

\begin{abstract}
In order to evaluate the present distribution patterns of salmonids and their potential effects on native fish, we sampled 11 large lakes and 105 streams, encompassing a total of 13 main hydrographic watersheds of southern Chile $\left(39^{\circ}\right.$ to $52^{\circ} \mathrm{S}$ ). Overall, trout (Salmo trutta and Oncorhynchus mykiss) accounted for more than $60 \%$ of total fish abundance and more than $80 \%$ of total biomass, while $40 \%$ of the streams sampled did not have native fish. Salmon, introduced for aquaculture, such as $O$. kisutch, Salmo salar, and O. tshawytscha, were only present in lakes with salmon farming and did not seem to be reproducing naturally in affluent streams. We tested the effect of river geographic origin (Andes mountains, central valley, or Coastal range) on fish abundance and found that rainbow trout was more restricted to the Andean streams with higher water discharge, while brown trout was widely distributed and did not relate to any of several catchment attributes measured. The abundance of native fish was greater in lakes than in streams and the highest native fish biodiversity occurred in streams of the central valley. The most common native species were Galaxias maculatus, G. platei, Brachygalaxias bullocki, Aplochiton zebra and Basilichthys australis. Streams with higher conductivity, larger pool areas, more fine sediments, and low brown trout densities were more suitable for native fish. Thus, catchments with higher anthropogenic disturbance appeared as refuges for native species. Given the descriptive nature of our study we can only presume the negative impacts of trout and salmon on native fish; an effect which should be superimposed on biogeographical conditioning of present distribution. Yet based on the present abundance and distribution patterns of salmonids and native fish, negative effects are very likely. Conservation of native fish biodiversity in central valley streams, far from protected areas or national parks and fully exposed to human perturbations represents a great challenge. We propose to enhance conservation by exerting a stronger sport fishing pressure on trout in those streams.
\end{abstract}

Key words: trout invasion, galaxid fish, salmon farming, catchments characteristics.

\section{RESUMEN}

Para evaluar la distribución y abundancia actual de salmónidos y peces nativos muestreamos 11 lagos grandes y 105 arroyos, cubriendo 13 cuencas principales en el sur de Chile desde $39^{\circ}$ a $52^{\circ} \mathrm{S}$. En general las truchas (Salmo trutta y Oncorhynchus mykiss) representaron más de $60 \%$ de la abundancia total de peces y más de 80 $\%$ de la biomasa total, además $40 \%$ de los arroyos muestreados no presentaron peces nativos. Los salmones traídos para acuicultura tales como $O$. kisutch, Salmo salar, y $O$. tshawytscha solo estuvieron presentes en lagos que tenían salmonicultura, aun cuando no parecen reproducirse exitosamente en los arroyos afluentes. Pusimos a prueba el efecto del origen de los arroyos (cordillera de los Andes, valle central o cordillera de la Costa) sobre la abundancia de las especies y encontramos que la trucha arco iris estuvo más restringida a los arroyos preandinos con mayor descarga, mientras la trucha café se distribuyó ampliamente no respondiendo a otras características o atributos específicos de las cuencas que se midieron. La abundancia relativa de peces nativos fue mayor en los lagos que en los arroyos, en tanto la mayor biodiversidad de peces nativos se encontró en arroyos del valle central. Las especies más comunes fueron Galaxias maculatus, G. platei, 
Brachygalaxias bullocki, Aplochiton zebra y Basilichthys australis. Arroyos con mayor conductividad, más áreas de pozones, más sedimentos finos y con bajas densidades de trucha café fueron más adecuados para peces nativos. Es así que cuencas con mayor disturbio antropogénico parecen ser refugio para los mismos. Dada la naturaleza descriptiva de nuestro estudio solo podemos presumir los efectos negativos de truchas y salmones sobre los peces nativos, efecto que debiera estar sobreimpuesto a los condicionantes biogeográficos de la distribución actual. Aun así, basado en las presentes distribuciones de salmónidos y peces nativos, los efectos negativos son muy probables. La conservación de la biodiversidad de peces nativos plenamente expuestos a perturbaciones humanas en el valle central, lejos de áreas protegidas y parques nacionales, presenta un gran desafío. Proponemos incentivar la conservación ejerciendo una mayor presión de pesca deportiva sobre las truchas en esos ambientes.

Palabras clave: invasión de truchas, peces galáxidos, salmonicultura, características de las cuencas.

\section{INTRODUCTION}

Exotic fish introductions to freshwater are a common occurrence. They often result from decisions taken by management agencies for the betterment of sports fishing or the development of aquaculture (Davidson \& Hutchinson 1938, Soto et al. 2001). Within these two categories, trout are among the most successful and better studied invaders around the world (Fausch et al. 2001).

Impacts of exotic freshwater fish are well assessed in many cases although concrete evidence is often lacking particularly regarding invasion mechanisms (Kolar \& Lodge 2000). This is particularly the case in Chile and Argentina, where trout (both rainbow and brown) are the most important and often the only freshwater fish known by common people. Nevertheless, there is still little quantitative information about their effect on native fish despite of them being mentioned as an important threat (Campos 1970, Vila et al. 1999). Salmon and trout are not native to the southern hemisphere and their evolution and natural distribution spans the northern hemisphere. They have since been introduced for sport fishing or aquaculture purposes in Australia, South Africa, New Zealand, and South America (McDowall 1968, Basulto 2003, Fausch et al. 2004). In Chile by early 1900, a government initiative facilitated the introduction of both, brown and rainbow trout (Salmo trutta and Oncorhynchus mykiss) to lakes and rivers along the country, particularly in the southern region, for sport fishing purposes (Basulto 2003). Presently, the largest populations of both trout species are found in the south of the country (beyond $36^{\circ} \mathrm{S}$ ) where important sport fishing takes place. There is also legal protection for the reproductive season of trout, and sport fishing is only allowed between late November and early May.

Indeed, trout are the best and perhaps the only known fish by most local people, as they are likely to be found in almost every stream and river in southern Chile and possibly in most catchments along the country. Unfortunately, at the time of the initial releases there were no studies on the potential effects of these exotic species on the native fauna. The prevailing attitude that justified the introductions by the late 1800 s and early 1900 s, particularly within governmental agencies, was that there were "empty niches" for salmonids in Chilean lakes and rivers as recalled by Campos (1970) and Basulto (2003). That is, there were plenty of places along the country where environmental conditions were ideal for salmonids and which "apparently" were not being used by other species. Extensive territorial reconnaissance were carried out to determine the best places to release the new comers and to build hatcheries for their propagation, extensively reviewed by Basulto (2003).

An additional potential threat to freshwater biodiversity, and even to trout sport fishing, came with the increasingly successful salmon farming industry in southern Chile. Salmon farming has experienced an exponential growth from less than 10,000 tons in 1988 , to a production of around 300 thousand tons in 2003 (Vergara 2003). The most commonly farmed species are Atlantic salmon (Salmo salar), coho salmon (Oncorhynchus kisutch), rainbow trout (Oncorhynchus mykiss), and to a much lesser extent, chinook salmon (Oncorhynchus tshawytscha).

Most salmon are anadromous, starting their life cycle in freshwater and migrating downstream through estuaries into the marine 
environment. Aquaculture mimics the natural cycle by developing the various growth stages in different water bodies, from streams, lakes to fjords of Chiloé (X Region) and Aysen (XI Region), the two most important salmon producing regions in Chile (Fig. 1). Throughout all these stages there numerous opportunities for fish to become free, due to either accidental escapes or intentional releases. Even when releases are penalized they still occur. Soto et al. (2001) followed massive salmon escapes during 1994 and 1995, when more than three million adult fish escaped after severe storms to the inner seas of Chiloé and Aysén, in southern Chile. The impact on freshwater systems was probably minor since there was no evidence of significant salmon runs derived from those escapes in streams and rivers (Soto et al. 2001).

There have been very few evaluations of the status of introduced salmonid species and native fish in freshwater ecosystems of southern Chile. Campos (1985) evaluated fish species distributions in the Valdivia river basin, and Campos et al. (1985) evaluated trout populations for sport fishing in some affluent streams to the Bueno river watershed. Recently, Soto \& Arismendi (2004) reported on the status and potential of small streams for the conservation of freshwater fish in the Bueno river watershed. However, up to now there is no detailed and comprehensive information on the distribution and impacts of salmon and trout over native fish in southern Chile. This is particularly relevant when there is a new threat from aquaculture, since there have been more salmon species and individuals introduced to lakes and rivers during the past 10 years than all previous private and State introduction efforts put together. Another factor to be considered is that rivers, streams, and major watersheds have been historically impacted to various degrees by human actions, such as deforestation and changes in land use (Lara et al. 1995). These perturbations cannot be neglected as they may also affect native fish biodiversity and invasion patterns of introduced salmonid species, they could have indeed facilitated invasion by the latter (Marchetti et al. 2004b).

Chilean freshwater fish fauna has a high degree of endemism, as well as an important circumpolar family component, Galaxias, shared with New Zealand (McDowall 1971). In all, for the whole country, there are about 45 freshwater fish species described in the literature (Campos et al. 1998); a rather reduced number considering the wide range of environments available along the country $\left(18^{\circ}\right.$ to $54^{\circ} \mathrm{S}$ ). Nearly $60 \%$ of those species are under some degree of vulnerability, and at least $30 \%$ are in serious danger (Campos et al. 1998) potentially experiencing local extinctions to which salmon and trout could be contributing.

The main purpose of our study is to asses the distribution and abundance of trout and salmon (thereafter referred as "salmonids") and native fish in freshwater ecosystems of southern Chile. Based on recent literature reviews and analyses on this topic which address the relevance of habitat disturbance (watershed properties) and native species "invisibility", due to low species richness (Marchetti et al. 2004a), we proposed some simple hypotheses such as: (a) patterns of invasions by salmonids should be related to human disturbances such as changes in land use (represented by native forest destruction) and water quality; (b) ecosystems with present salmon farming should have some of the new salmon species getting established as many escapes have been reported; (c) assuming that salmonids may have impacted native fish we could expect the latter to have better conservation status in watersheds with more pristine conditions.

\section{MATERIAL AND METHODS}

Chile is a long, slender country which runs from $18^{\circ}$ to $54^{\circ} \mathrm{S}$, with the Andes mountains as a major natural geographical barrier to the east, the Pacific Ocean to the west, and the desert to the north; thus, constituting a very isolated territory from a biogeographical perspective. All main hydrographic watersheds in the country (except one in Tierra del Fuego), run from the Andes mountains to the Pacific Ocean, forming parallel watersheds (Fig. 1). Within each watershed, some rivers (the largest proportion) originate in the Andes (Andean or pre-Andean rivers). Others originate in the central valley (central valley rivers), and others originate in the Coastal mountain range (Coastal range rivers), flowing east for a short 


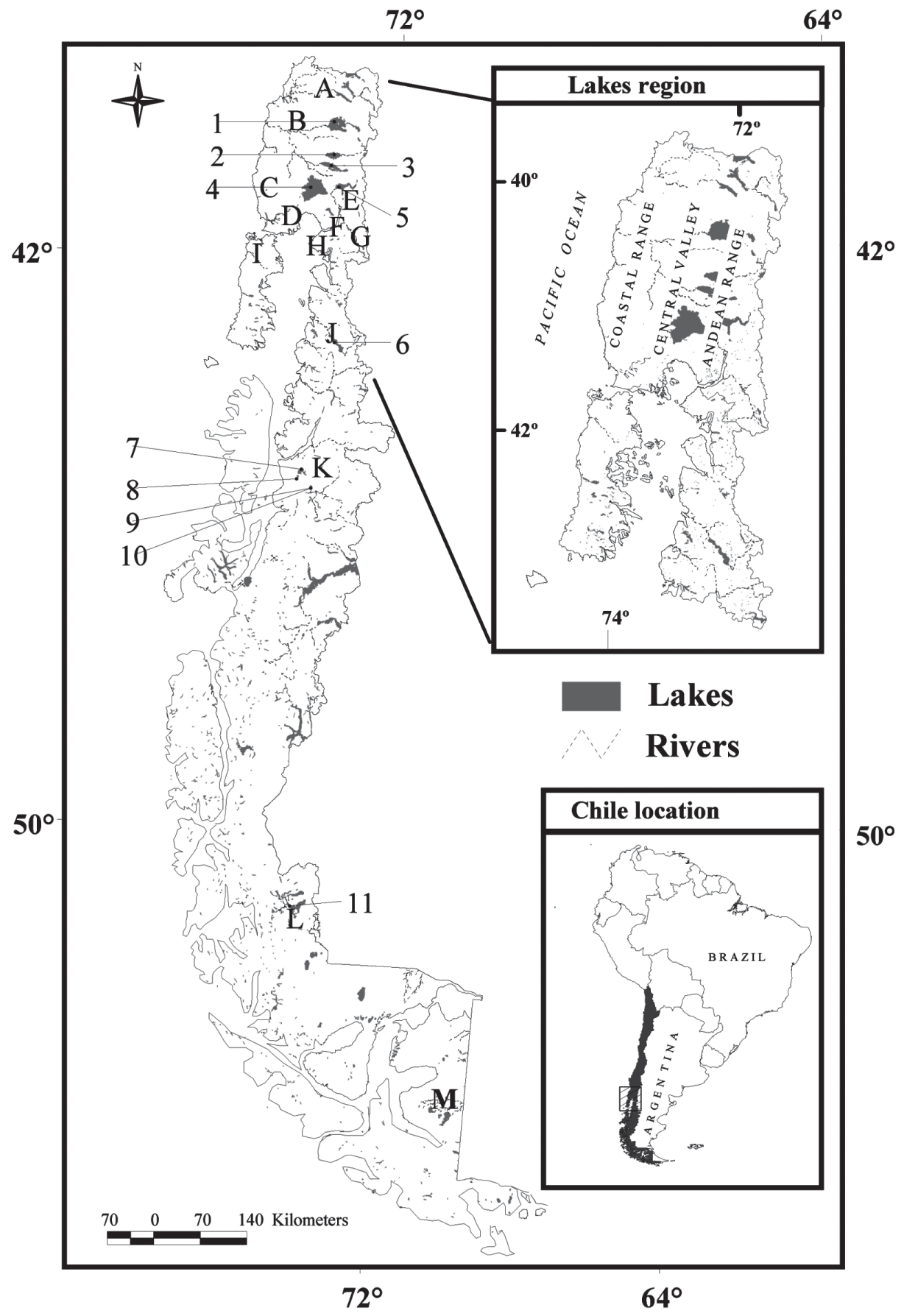

Fig. 1: Southern Chile map showing the major watersheds being reported in this study. The enlargement represents the Lakes Region where the most intensive sampling took place. Lakes: $1=$ Ranco, 2 = Puyehue, $3=$ Rupanco, $4=$ Llanquihue, $5=$ Todos Los Santos, $6=$ Yelcho, $7=$ Los Palos, 8 = Yulton, $9=$ Meullín, $10=$ Cóndor, $11=$ Toro.

Main watersheds: $\mathrm{A}=$ Valdivia, $\mathrm{B}=$ Bueno, $\mathrm{C}=$ Llico, $\mathrm{D}=$ Maullín, $\mathrm{E}=$ Puelo, $\mathrm{F}=$ Petrohué, $\mathrm{G}=$ Puelche, $\mathrm{H}=$ Hornopirén, $\mathrm{I}=\mathrm{Chepu}, \mathrm{J}=$ Yelcho, $\mathrm{K}=$ Nirehuao, $\mathrm{L}=$ Serrano, $\mathrm{M}=$ Rasmussen.

Mapa del sur de Chile indicando las principales cuencas reportadas en este estudio. En la ampliación se ilustra la Región de Los Lagos donde el muestreo fue más intensivo. Lagos: $1=$ Ranco, $2=$ Puyehue, $3=$ Rupanco, $4=$ Llanquihue, $5=$ Todos Los Santos, $6=$ Yelcho, $7=$ Los Palos, $8=$ Yulton, $9=$ Meullín, $10=$ Cóndor, $11=$ Toro.

Cuencas principales: $\mathrm{A}=$ Valdivia, $\mathrm{B}=$ Bueno, $\mathrm{C}=$ Llico, $\mathrm{D}=$ Maullín, $\mathrm{E}=$ Puelo, $\mathrm{F}=$ Petrohué, $\mathrm{G}=$ Puelche, $\mathrm{H}=$ Hornopirén, $\mathrm{I}=$ Chepu, $\mathrm{J}=$ Yelcho, $\mathrm{K}=$ Nirehuao, $\mathrm{L}=$ Serrano, $\mathrm{M}=$ Rasmussen. 
distance and then joining the main watershed to flow west into the Pacific Ocean (Fig. 2). There are a few short streams/ rivers between $40^{\circ} \mathrm{S}$ and $43^{\circ} \mathrm{S}$ which originate in the Coastal range and flow directly into the Pacific Ocean. These streams were not sampled since they do not connect to any major watershed and are not yet accessible for adequate sampling.

South from $38^{\circ} \mathrm{S}$ latitude, large lakes of glacial origin are located near the heads of most hydrographic watersheds, so those flow regimes are characterized by their "lacustrine regulation" (Fig. 1).

The study area considered in this investigation is centered in southern Chile, from $38^{\circ}$ to $54^{\circ} \mathrm{S}$ (Fig. 1). This is a region where the most important fresh water reserves in the whole territory are found. It is also where the invasion potential by salmonids is likely to be the highest since greater introduction efforts were made (Basulto 2003). This region also corresponds to the geographical area where the most intensive salmon farming takes place.

To get a broad understanding of native fish and introduced salmonids status in lakes, we used all the information we have gathered from various different research initiatives over the past decade or more. Thus, here we integrated information from streams and lakes sampled with different methodologies according to the type of water body. During a year period, large lakes, such as Ranco and Puyehue were sampled monthly while Lago Llanquihue was sampled bimonthly. Main characteristics of these lakes and the number of samples collected are found in Table 1. Information collected in previous sampling programs such as remote lakes from Torres del Paine National Park was also used. Each sampling considered between two and four days of gill nets deploying. The nets were $70 \mathrm{~m}$ long and $3.5 \mathrm{~m}$ in depth each, with stretched mesh sizes of $1 \frac{1}{2}$, $3,4 \frac{3}{4}$, and 6 inches. Once deployed, these gill nets formed a wall perpendicular to the shore. They were efficient at capturing pelagic fish, most of which inhabit the platform shelf of these deep glacial lakes (Sanzana 2003). The nets were deployed at night, remaining at the site for at least $48 \mathrm{~h}$ and were checked every 8 hrs when fish were collected and taken for further analysis. Catch per unit effort (CPUE) was the unit of sampling effort standardized for all lakes and was calculated as the number of individuals captured per hour of total deployment time, for the set of nets used in each case. All fish captured were identified, measured (total length) and weighed (wet weight). No fish were returned to the lake as most of them were killed by this fishing method.

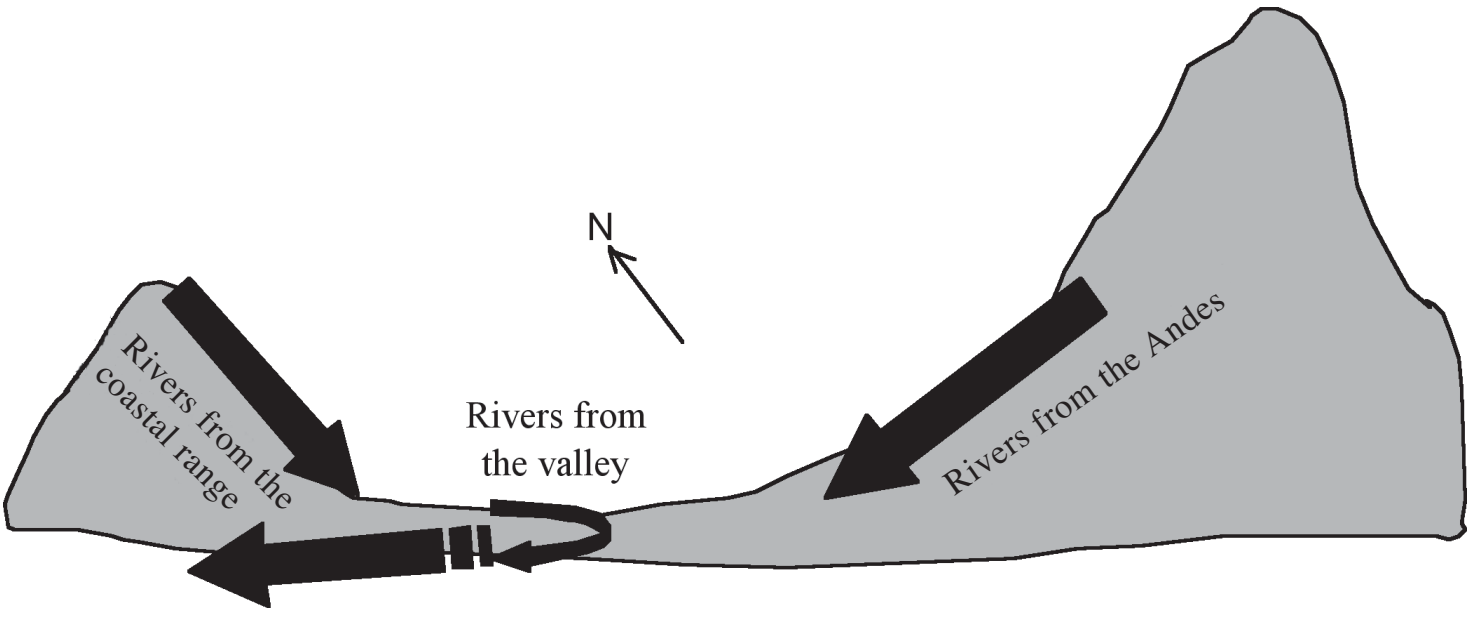

Fig. 2: Schematic representation of streams originating from the Andes mountains, central valley, and Coastal range. Arrows indicate drainage direction including those of larger catchments flowing to the Pacific Ocean.

Representación esquemática de los arroyos que nacen de los Andes, del valle central y de la cordillera de la Costa. Las flechas indican la dirección de las aguas incluyendo el drenaje final hacia el océano Pacífico en las cuencas principales. 
TABLE 1

Characteristics and location of 11 lakes included in the study. We indicate the number of sampling events (n) during a particular study period. We also indicate when salmon farming is present (+) and the number of salmon and trout species recorded

Características y ubicación de 11 lagos incluidos en este estudio. Se indica el número de muestreos (n) realizados durante los diferentes períodos de estudio. También se indica la presencia de salmonicultura (+) y el número de especies de salmones y truchas presentes

\begin{tabular}{|c|c|c|c|c|c|c|c|c|}
\hline \multirow[t]{2}{*}{ Lake } & \multirow[t]{2}{*}{ Latitude ${ }^{\circ} \mathrm{S}$} & \multirow{2}{*}{$\begin{array}{l}\text { Area } \\
\left(\mathrm{km}^{2}\right)\end{array}$} & \multirow{2}{*}{$\begin{array}{c}\text { Mean } \\
\text { depth }(m)\end{array}$} & \multicolumn{2}{|c|}{ Sampling scheme } & \multirow{2}{*}{$\begin{array}{l}\text { Salmon } \\
\text { farming }\end{array}$} & \multicolumn{2}{|c|}{ Salmon and trout species } \\
\hline & & & & $\mathrm{n}$ & Year & & Salmon & Trout \\
\hline Ranco & $40^{\circ} 13^{\prime}$ & 443 & 122 & 13 & 2000 & + & 3 & 2 \\
\hline Puyehue & $40^{\circ} 10^{\prime}$ & 165 & 76 & 13 & 2000 & + & 3 & 2 \\
\hline Rupanco & $40^{\circ} 50^{\prime}$ & 236 & 162 & 6 & 2001 & + & 3 & 2 \\
\hline Llanquihue & $41^{\circ} 08^{\prime}$ & 870 & 182 & 6 & 2000 & + & 3 & 2 \\
\hline Todos Los Santos & $41^{\circ} 10^{\prime}$ & 179 & 190 & 3 & 1998 & - & 1 & 2 \\
\hline Yelcho & $43^{\circ} 18^{\prime}$ & 120 & 135 & 6 & 2001 & + & 2 & 2 \\
\hline Los Palos & $45^{\circ} 27^{\prime}$ & 7.3 & 39 & 2 & 1997 & + & 0 & 2 \\
\hline Yulton & $45^{\circ} 06^{\prime}$ & 62 & $<80$ & 2 & 1997 & - & 0 & 0 \\
\hline Meullín & $45^{\circ} 04^{\prime}$ & 9.4 & $<80$ & 2 & 1997 & - & 0 & 0 \\
\hline Cóndor & $45^{\circ} 28^{\prime}$ & 11 & $<50$ & 2 & 1997 & - & 0 & 1 \\
\hline Toro & $51^{\circ} 12^{\prime}$ & 196.4 & 155 & 7 & 1989 & - & 0 & 2 \\
\hline
\end{tabular}

Along and after lake sampling, several streams on each main watershed were sampled from January 1999 to May 2004; most were third to fourth order streams with average discharges varying from 700 to $3,000 \mathrm{~L} \mathrm{~s}^{-1}$ except for Petrohué river, a much larger river which was sampled at Los Patos, near the outflow of Lago Todos Los Santos. Relevant information on sampling and characteristics of watersheds are given in Table 2. In total, we sampled 105 streams belonging to 13 major watersheds (Fig. 1). In most cases each stream was sampled at least twice, in the drier summerfall season (December to April) and again in the rainy winter-spring season (May to November). The most intensive sampling effort was made in the Lakes Region ( $39^{\circ}$ to $42^{\circ} \mathrm{S}$ ) during 2002 to 2003 in streams and rivers connected to lakes or coastal zones where salmon farming occurs. Each sampling included wading along a portion of the stream with a "Smith and Root Model $12 \mathrm{~B}$ " electro fishing equipment, covering a reach that was at least 10 times as long as the mean width of the stream or river. The area sampled normally covered between 300 to 1,500 $\mathrm{m}^{2}$ to account for all the different habitats of a particular stream. The fishing method had a failure rate of less than $8 \%$ as we took enough time to make sure all the fish were at least spotted. The average failure rate was evaluated on several occasions for different stream habitat conditions by setting a seine net down stream, where the fish which escaped direct collection from electro fishing were then caught, identified and counted. On the other hand, data variability among sampling dates for each stream was low, both regarding the list of species found ( $\mathrm{CV}$ on number of species $<5 \%$ ) and the relative abundance of each with CVs less than $20 \%$ (Soto et al. unpublished data). All fish collected were first anesthetized with MS 222® and were then measured and weighed. In many instances, we took a fish sub-sample for the analysis of stomach contents, although those results will be reported elsewhere. For data analysis we only used total length and wet weight as most individuals captured with this method were subsequently released. More detailed analyses on spatial and temporal variability of streams fish fauna will be published elsewhere (Soto et al. unpublished data). The information gathered from 105 streams was used to describe geographical distribution and abundance of salmonids and native fish. 
TABLE 2

Location and main physical characteristics of main watersheds and the number of third and fourth order streams sampled in each one. The number of species of native fish and salmonids in each watershed is also indicated as well as the ratio of rainbow trout to brown trout density. Latitude corresponds approximately to the central point of the watershed running East-West (Except

\section{Rasmussen which runs from West to East)}

Tabla 2. Ubicación y principales características físicas de las principales cuencas y de sus afluentes de tercer a cuarto orden que fueron muestreados. Se indica además el número de especies salmonídeas de cada cuenca y la razón entre las densidades de trucha arco iris y café. La latitud corresponde aproximadamente al punto central de la cuenca que corre de este a oeste (excepto Rasmussen que corre de oeste a este)

\begin{tabular}{|c|c|c|c|c|c|c|c|}
\hline Main watershed & $\begin{array}{l}\text { Latitude } \\
{ }^{\circ} \mathrm{S}\end{array}$ & $\begin{array}{l}\text { Watershed } \\
\text { area }\left(\mathrm{km}^{2}\right)\end{array}$ & $\begin{array}{l}\text { Length of main } \\
\text { watershed }(\mathrm{km})\end{array}$ & $\begin{array}{c}\text { Number of } \\
\text { streams } \\
\text { sampled }\end{array}$ & $\begin{array}{c}\text { Number of } \\
\text { native } \\
\text { species }\end{array}$ & $\begin{array}{c}\text { Number of } \\
\text { salmonid } \\
\text { species }\end{array}$ & $\begin{array}{c}\text { Rainbow/ } \\
\text { brown trout }\end{array}$ \\
\hline Valdivia & $39^{\circ} 50^{\prime}$ & 9,902 & 150 & 12 & 6 & 3 & 1.3 \\
\hline Bueno & $40^{\circ} 10^{\prime}$ & 17,210 & 130 & 45 & 8 & 4 & 2.8 \\
\hline Llico & $41^{\circ} 20^{\prime}$ & 1,400 & 80 & 3 & 3 & 2 & 0.2 \\
\hline Maullín & $41^{\circ} 33^{\prime}$ & 4,298 & 85 & 16 & 7 & 4 & 1.0 \\
\hline Petrohué & $41^{\circ} 10^{\prime}$ & 2,644 & 63 & 4 & 3 & 3 & 1.9 \\
\hline Puelche & $41^{\circ} 43^{\prime}$ & 80 & 12 & 1 & 1 & 3 & 0.1 \\
\hline Puelo & $41^{\circ} 33^{\prime}$ & 8,817 & 123 & 2 & 1 & 3 & 0.4 \\
\hline Hornopirén & $41^{\circ} 50^{\prime}$ & 127 & 20 & 7 & 1 & 4 & 1.0 \\
\hline Chepu & $42^{\circ} 16^{\prime}$ & 197 & 48 & 2 & 5 & 1 & 0 \\
\hline Yelcho & $43^{\circ} 13^{\prime}$ & 10,979 & 246 & 3 & 0 & 2 & 8.7 \\
\hline Nirehuao & $45^{\circ} 13^{\prime}$ & 120 & 150 & 1 & 0 & 1 & 0 \\
\hline Serrano & $51^{\circ} 06^{\prime}$ & 7,347 & 38 & 6 & 1 & 2 & 0 \\
\hline Rasmussen & $53^{\circ} 50^{\prime}$ & 784 & 60 & 3 & 0 & 2 & 0.02 \\
\hline
\end{tabular}

In order to test our hypotheses and to understand salmonid distribution patterns we used information collected from 34 streams of the Lakes Region (Fig. 1) where we had better access to sites and had more information including forest cover of the catchments. We applied multiple regression analysis using several stream habitat characteristics as independent variables, which in the case of native fish also included trout abundance as a potential predictor. The sum of all "native fish species" was considered as a single group mainly because the abundance of individual species was very sparse and was often restricted to single streams. More detailed analysis on individual species is being prepared for additional publications.

Most physical and chemical data collected could be related to habitat disturbance and thus could help to the hypothesis testing. These data were collected simultaneously on each fish sampling event. Such was the case of conductivity, temperature, dissolved oxygen, and $\mathrm{pH}$, which were measured with portable
Thermo Orion ${ }^{\circledR}$ sensors. We also collected information on dissolved nutrients $\left(\mathrm{NO}_{3}, \mathrm{NH}_{4}\right.$ and $\mathrm{PO}_{4}$ ) from samples taken on each stream (Cuevas et al. unpublished data). Water discharge was also measured at least in three points along each stream sampled by evaluating discharge area and water velocity with a velocity meter placed in the middle of the reach at about $40 \mathrm{~cm}$ from the bottom. Other characteristics of streams included: estimated vegetation cover (shade) on the water surface along the sampled reach, the approximate proportion with riffles or pools on the sampled reach, the bottom structure (percentage of bottom area covered by fine sediments, cobbles and large rocks), water transparency measured with qualitative scale from cero to five (cero indicates no possibility to see the bottom on a water column of $50 \mathrm{~cm}$, while five indicates transparent waters), and the estimated percentage of periphyton cover on bottom cobbles and rocks. We also used a series of additional variables as predictors of fish abundance, such as the stream origin (Andes 
mountains, central valley, or Coastal range), latitude, longitude, main watershed to which the stream belongs and the stream catchment area. More details on stream sampling and water analyses will be published elsewhere.

Another independent variable used to test our hypothesis and to predict salmonid and native fish abundance was the percentage area covered by native forest as a potential measure of perturbation, assuming that a catchment with $100 \%$ of native forest could be considered more pristine. To obtain this information, digital orthophotos of watersheds were produced from aerial photographs taken at a scale of 1:8,000 - 1:10,000 during 2002. Using these, homogeneous cartographical units were defined and all watersheds were verified in the field for an adequate delimitation and improved description of the units, particularly those covered by native forest. Later on, maps were prepared with Geographic Information System using the software ArcView $3.2 ®$ (Environmental Systems Research Institute, Inc., USA). More complete information on land use effects on stream ecology is being published elsewhere (Cuevas et al. unpublished data)

For the multivariate analysis, data consisted of average values for each stream corresponding to the dry season sampling. We did not use the incomplete wet season data set since many streams were not accessible then for electrofishing. We applied the forward stepwise multiple regression protocol (Sokal \& Rohlf 1995), using the software Statistica 6.0® (StatSoft, Inc., Tulsa, Oklahoma, USA) Module Statistics, Multiple Regression: the F-to-enter was set to 0.0001 and the F-to-remove to cero. To avoid multi colinearity among predictor variables we previously developed a correlation matrix among all variables and only used in the models those which where uncorrelated. Among those, we selected the most inclusive ones trying to leave no more that four at the end, given our sample size (34). We also used natural Log transformations when needed to normalize residuals of dependent variables.

We also tested the effect of river origin (Andes mountains, central valley, or Coastal range) on trout and native fish abundance by applying ANOVA; data used were natural Log transformed to comply with normality assumptions; we further compared the three groups with Tukey's HSD test. For the ANOVA and "post-hoc" test we used a larger data set for the Lakes Region, 49 streams in total; 17 from the Andes, 16 from the Central valley and 17 from the Coastal range. Thus, streams were treated as replicates for each "origin". In this case we also used mean values for the dry season.

\section{RESULTS}

Tables 1 and 2 show main characteristics of lakes and main watersheds sampled, including species richness. The Appendix shows main watershed variables, including mean percent coverage of native forest and biological variables for streams in the Lakes Region, which were later used in the multiple regression analysis.

During our surveys we collected and identified 11 native fish species and seven introduced species (Table 3). Of the latter, five were the widely spread salmonid species while the other two were the common carp (Cyprinus carpio) and the mosquito fish (Gambusia affinis), both restricted to the Río Bueno watershed and north of this watershed (Soto \& Arismendi 2004).

All the large lakes in southern Chile have populations of salmon and trout, and for some of them, such as Yelcho river, no native pelagic species were captured by our sampling method. Rainbow trout and brown trout were the main salmonid species in lakes without salmon farming (Table 1, Fig. 3). Lakes where salmon are cultivated had up to five salmonid species including rainbow trout, chinook, coho, and Atlantic salmon, while brown trout was rare in these lakes. When the numbers were converted to biomass, salmon and trout accounted for more than $80 \%$ of total fish biomass in all the lakes where they are present. Only in a set of two connected lakes, Yulton-Meullin in the Andes mountains of Aysen did we not find any salmon or trout. In these lakes we found the largest population of native species, Galaxias platei, "puye grande" and also Aplochyton zebra, "peladilla" (Fig. 4).

Contrasting with lakes, trout (rainbow and brown) were the most important component of the fish fauna in streams and rivers, accounting for more than $95 \%$ of total biomass. Only 13 
TABLE 3

Native and introduced species identified in this study. Present taxonomical classification according to Dyer (2000)

Especies nativas e introducidas identificadas en este estudio. La clasificación taxonómica corresponde a Dyer (2000)

\begin{tabular}{lll}
\hline Order & Family & Species \\
\hline & & Native \\
Petromyzontiformes & Petromizontidae & Geotria australis (lamprea) \\
Characiformes & Characidae & Cheirodon australe (pochita) \\
Siluriformes & Trichomycteridae & Trichomycterus aerolatus (bagrecito) \\
Osmeriformes & Galaxiidae & Galaxias maculatus (puye chico) \\
Osmeriformes & Galaxiidae & Galaxias platei (puye grande) \\
Osmeriformes & Galaxiidae & Brachygalaxias bullocki (puye rojo) \\
Atheriniformes & Galaxiidae & Aplochiton zebra (peladilla) \\
Atheriniformes & Atherinopsidae & Basilichthys australis (pejerrey) \\
Perciformes & Atherinopsidae & Cauque mauleanum (cauque) \\
Perciformes & Percichthyidae & Percichthys trucha (perca) \\
& Perciliidae & Percilia gillisi (carmelita) \\
Cypriniformes & & Introduced \\
Salmoniformes & Cyprinidae & Cyprinus carpio (carpa) \\
Salmoniformes & Salmonidae & Oncorhynchus tshawytscha (chinook) \\
Salmoniformes & Salmonidae & O. kisutch (coho) \\
Salmoniformes & Salmonidae & Salmo salar (salar) \\
Salmoniformes & Salmonidae & S. trutta (trucha café or brown) \\
Cyprinidontiformes & Salmonidae & O. mykiss (trucha arcoiris or rainbow) \\
\hline
\end{tabular}

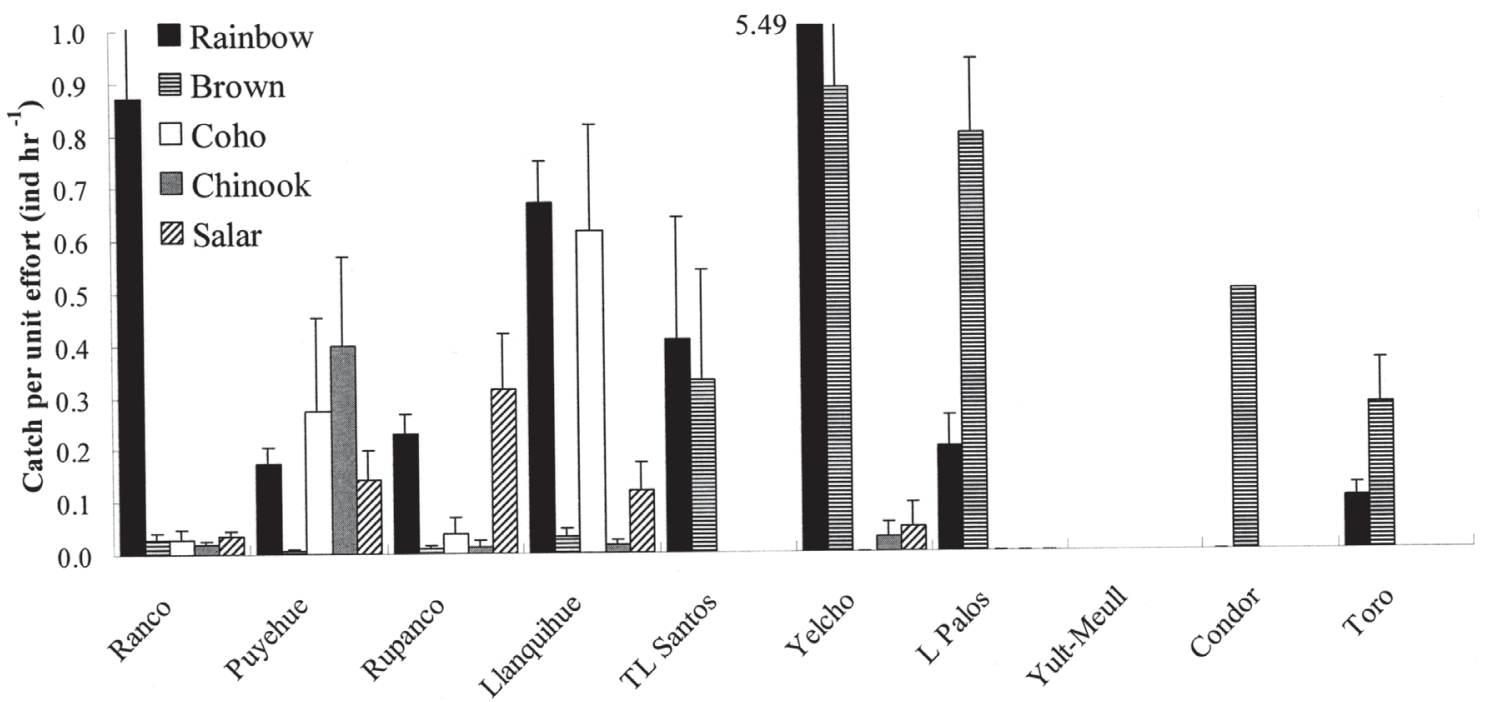

Fig. 3: Mean relative abundance (capture per unit effort, CPUE) plus 1 SE (standard error), for each salmonid species in lakes from north to south (left to right). The bar for rainbow trout in Lago Yelcho was truncated to better fit the figure, since that mean CPUE value corresponds to 5.49 plus 0.6 for SE.

Abundancia relativa promedio (captura por unidad de esfuerzo, CPUE) más 1 EE (error estándar) para cada especie salmonídea en lagos, de norte a sur (izquierda a derecha). La barra para trucha arco iris en el lago Yelcho está truncada para ajustar mejor la figura, dado que ese valor promedio de CPUE corresponde a 5.49 más 0.6 EE. 


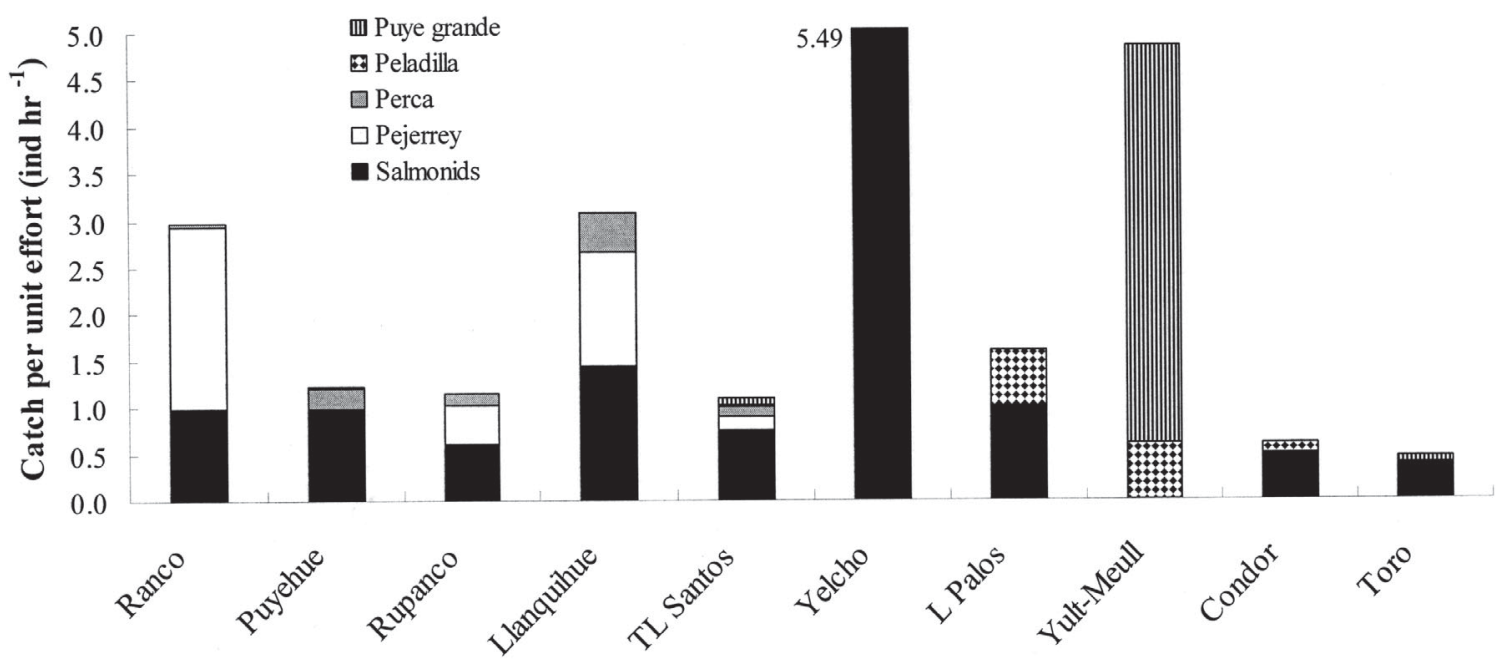

Fig. 4: Accumulated mean relative abundance (capture per unit effort, CPUE) for salmonids (all grouped together) and native species (common names are used as explained in Table 3) in lakes from north to south (left to right). The bar for salmonids is truncated as explained in Fig. 3 .

Abundancia acumulada promedio (captura por unidad de esfuerzo, CPUE) para salmonídeos (todas las especies agrupadas) y peces nativos (nombres comunes descritos en la Tabla 3) en lagos de norte a sur (izquierda a derecha). La barra para salmonídeos está truncada como se explicó en la Fig. 3.

of the 105 streams sampled had some individuals of Atlantic salmon, but these streams were directly connected to salmon hatcheries and those fish, most likely, had recently escaped. A couple of streams in the Puelo river and Petrohué watersheds had young chinook salmon, which correspond to reported reproductive populations there. Brown trout was present in all watersheds while rainbow trout was absent or had very low representation in the southernmost watersheds (Table 2). In the Lakes Region both trout species were about equally represented in density considering the major watersheds as a whole. The exception was in Yelcho river where rainbow trout was absolutely dominant (Table 2).

In most watersheds we did check some first and second order streams and in few occasions we found trout juveniles but very rarely native fish, thus we concentrated our efforts in third to fourth order streams. In most watersheds south of $42^{\circ} \mathrm{S}$ latitude, trout seemed to be the only inhabitants of third and fourth order streams, while native fish densities and species richness had their maximum in the Bueno river and Maullín river watersheds (Fig. 5, Table 2). The most abundant native species were Galaxias platei, Galaxias maculatus, and Brachygalaxias bullocki. They were respectively present in 28
$\%, 25 \%$, and $22 \%$ of the rivers sampled. Other less frequently found species that also exhibited lower abundance were Aplochiton zebra, and Cheirodon australe. More specific information on individual native species will be published elsewhere.

Size distributions of native fish ranged between 1.3 and $32.5 \mathrm{~cm}$ in total length, with an average of $5.5 \mathrm{~cm}$; while salmonids showed a size range between 2 and $45 \mathrm{~cm}$ total length with an average of $10.2 \mathrm{~cm}$.

The relationship between abundance of trout and native species was inverse and not lineal (Fig. 6); trout reached much higher densities than native fish (Fig. 7). This was also true for biomass (Fig. 8). In fact, there were very few streams without trout; only four of those sampled in the Lakes Region. Therefore, we were unable to compare streams with and without trout. Figure 6 shows that a natural Log transformation of numbers did not give a better relationship among data due to the absence of native fish in too many streams. Additionally, when we classified streams according to their origin in the Lakes Region (Fig. 2), the proportion of streams that did not have native fish corresponded to $75 \%$ of the Andean, $19 \%$ of those in the central valley, and $29 \%$ of those in the Coastal range. 


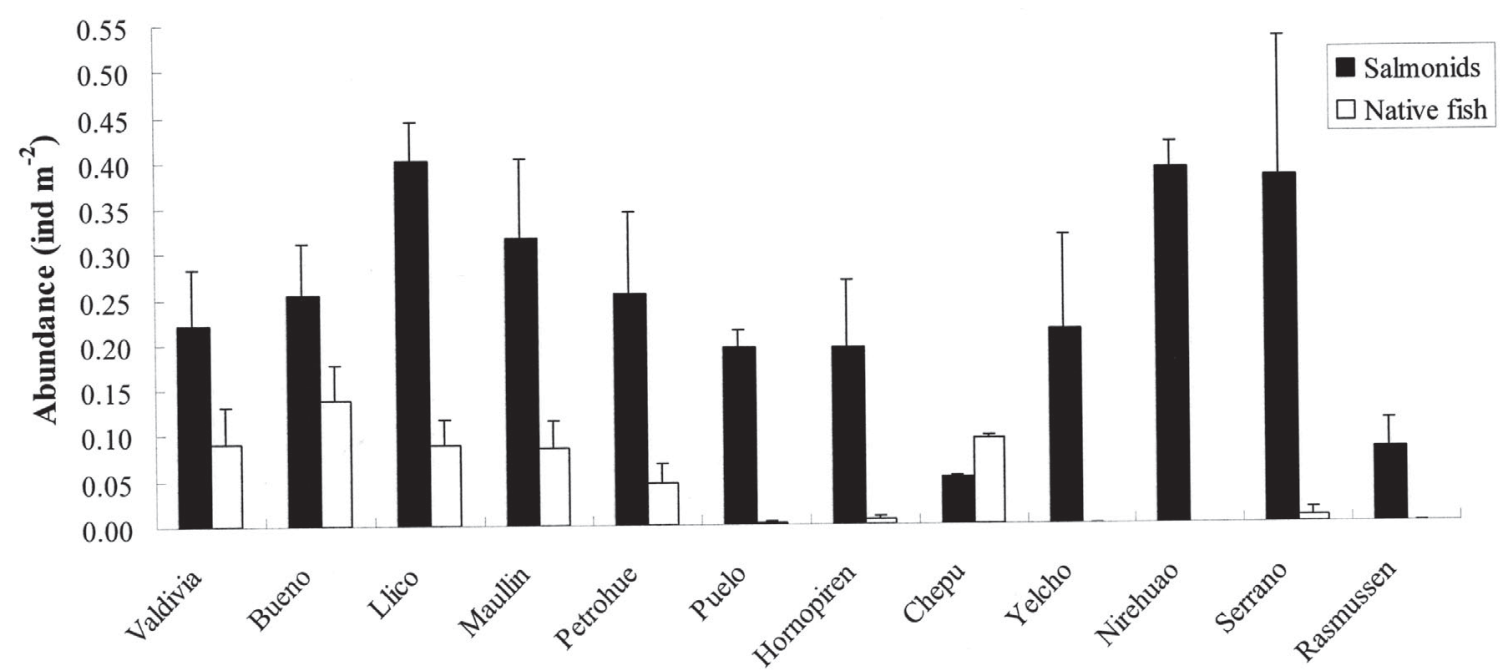

Fig. 5: Mean density (individuals $\mathrm{m}^{-2}$ ) of native fish and salmonids plus $1 \mathrm{SE}$ in third to fourth order streams at each major watershed from north to south. The number of streams considered for each main watershed as in Table 2.

Densidad promedio (individuos $\mathrm{m}^{-2}$ ) de peces nativos y salmonídeos más $1 \mathrm{EE}$ en arroyos de tercer a cuarto orden de las cuencas principales de norte a sur. El número de arroyos considerados en cada cuenca se indica en la Tabla 2.

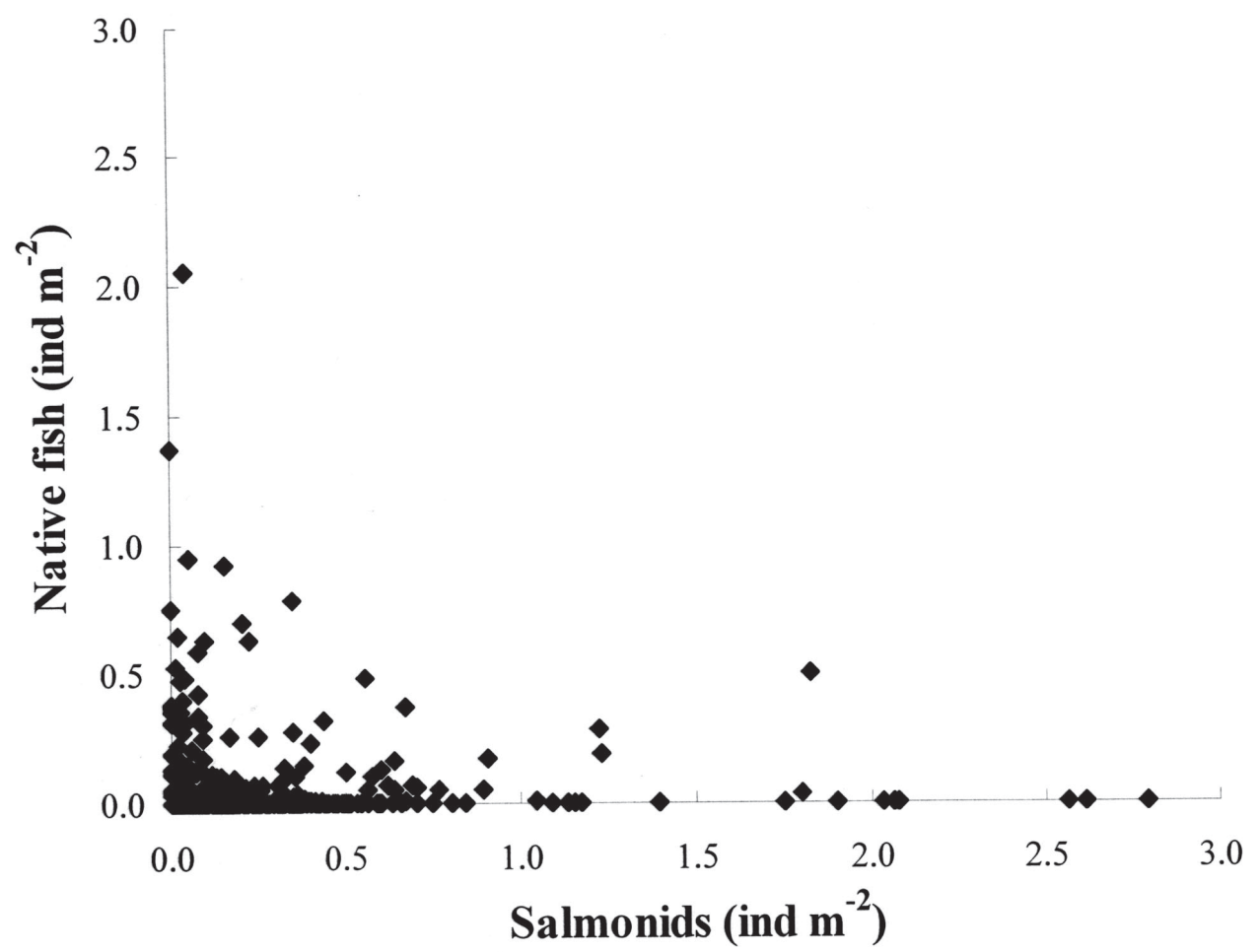

Fig. 6: Relationship between average native fish (all species grouped) and salmonids (all species grouped but mostly trout) density (individuals $\mathrm{m}^{-2}$ ) in 105 streams.

Relación entre la densidad promedio (individuos $\mathrm{m}^{-2}$ ) de peces nativos (todas las especies agrupadas) y los salmonídeos (todas las especies agrupadas, pero principalmente truchas) en 105 arroyos. 


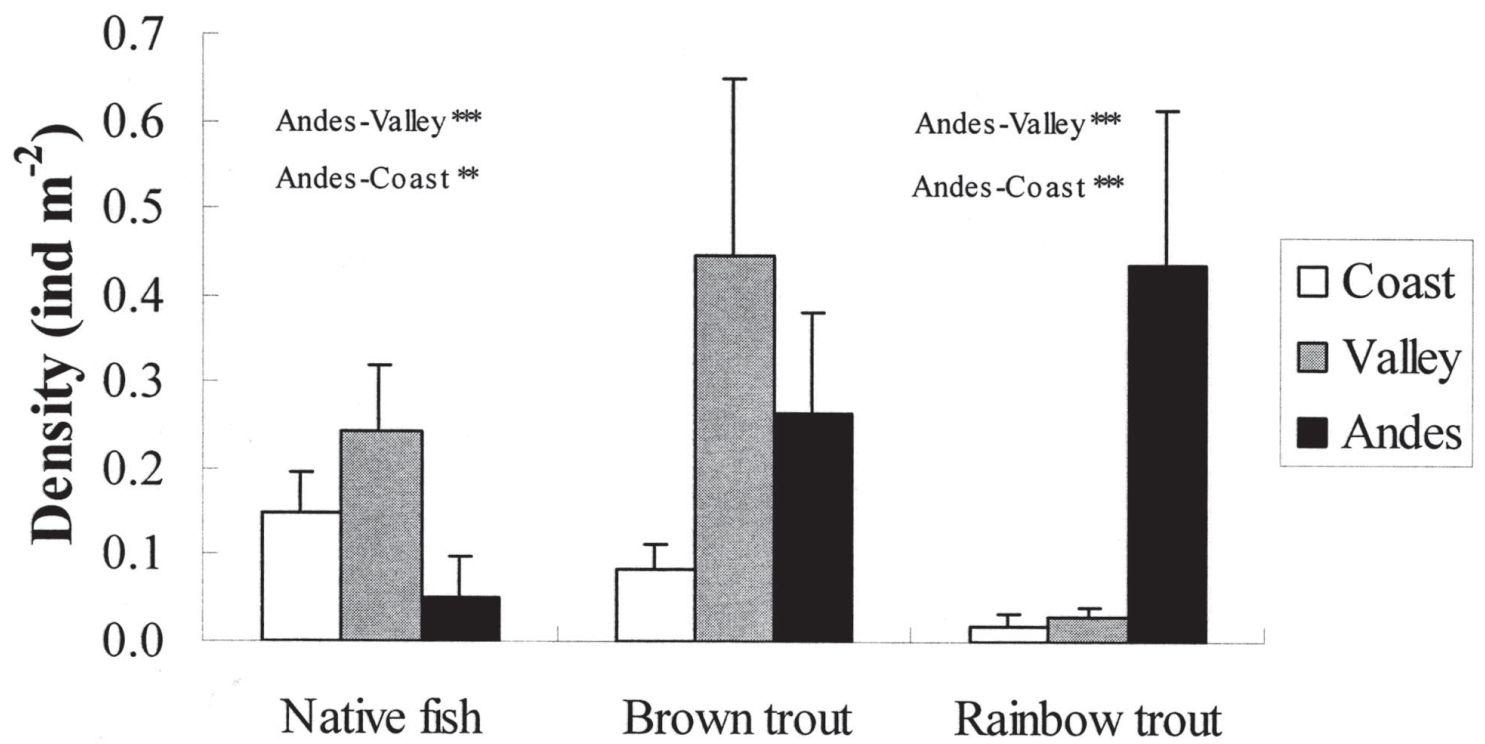

Fig. 7: Mean density of brown trout, rainbow trout, and native fish (all species grouped) in streams of the Lakes Region born in the Andes mountains (A), the central valley (V), and the Coastal range (C). Results of a "post-hoc" Tukey comparison test among means are indicated. Only significant differences are shown with asterisks according to: $\mathrm{P}<0.001=* * *, \mathrm{P}<0.01=* *$.

Densidad promedio de trucha café, arco iris y peces nativos (todas las especies agrupadas) en arroyos de la Región de Los Lagos que nacen en la cordillera de los Andes (A), el valle central (V) y la cordillera de la Costa (C). Se indica la significación estadística de la comparación "a posteriori" de las medias usando una prueba de Tukey. Solo se indican las diferencias significativas con asteriscos $\mathrm{P}<0.001=* * *, \mathrm{P}<0.01=* *$.

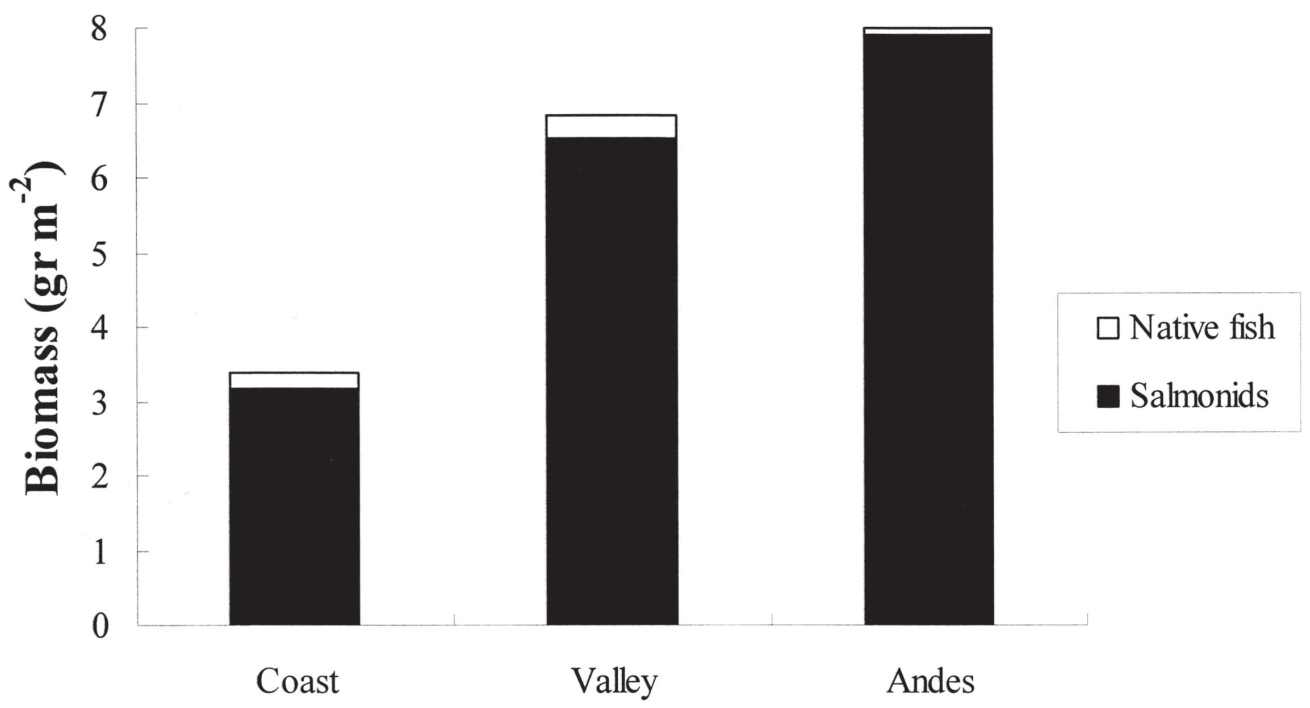

Fig. 8: Mean fish biomass (salmonids and native) in streams of the Lakes Region born in the Andes mountains (A), the central valley $(\mathrm{V})$, and the Coastal range (C).

Biomasa promedio de peces (salmonídeos y nativos) en arroyos de la Región de Los Lagos que nacen en: la cordillera de los Andes (A), el valle central (V) y la cordillera de la Costa (C). 
An ANOVA to test the effect of river origin (Andes mountains, central valley, or Coastal range) showed a significant effect both for rainbow trout and for native species (Table 4). Indeed, rainbow trout were significantly more abundant in Andean streams than in those from the central valley or the Coastal range (Fig. 7), while native fish abundance was significantly higher in the central valley and the Coastal range streams. On the other hand, brown trout had apparently higher densities in the Central valley streams but with greater variability and not showing significant origin effect (Fig. 7). Regarding biomass, trout were overwhelmingly dominant to native fish in all three types of streams (Fig. 8).

Table 5 shows results of a forward stepwise multiple regression analysis, where we initially used 20 to 22 independent variables from streams in the Lakes Region (Appendix) to explain trout and native fish density. The best predictive model for native fish density $\left(\mathrm{R}^{2}=\right.$ $0.65)$ was directly related to percentage fine sediment on the stream bed, conductivity, percent of pools in the sampled area, and it was negatively related to brown trout density (Table 5). Native fish species richness showed also a significant but lower adjusted $\mathrm{R}^{2}(0.58)$, and had a negative partial correlation with longitude, while being positively related with percent of fine sediment, maximum water temperature, and $\mathrm{N}-\mathrm{NH}_{4}$. For rainbow trout, the best model had an $\mathrm{R}^{2}$ of 0.53 being directly related to the longitudinal position (west) and to water discharge, while negatively related to percent of pools and to submerged vegetation coverage (Table 5). Brown trout had a poorer $\mathrm{R}^{2}$ of 0.32 being directly related to conductivity and negatively related to the catchment area, the terrestrial vegetation cover (shading) on the stream, and the percentage of fine sediment on the bottom (Table 5). The percentage of native forest covering the catchment area was not a good predictor variable for any of the three fish groups as it did not enter any of the models.

\section{DISCUSSION}

The successful spread of exotic trout and salmon has been well studied in similar environments such as New Zealand (McDowall 2003) and southern Argentina (Pascual et al. 2002). As pointed out by Peterson \& Fausch (2003), introductions of stream salmonids are widespread, being rainbow trout and brown trout the topmost invasive species. They often invade simple systems particularly those with low fish species diversity, and some degree of habitat degradation.

Indeed, reasons for the successful invasion reported from southern Chile could be related to the excellent abiotic conditions, absence or low predation pressure (Soto et al. 2001), and few native fish species as potential competitors or predators (Campos et al. 1998); all of these characteristics potentially constitute a high risk of invasibility (Case 1991).

\section{TABLE 4}

Analysis of variance of natural Log- transformed data to evaluate the effect of river origin on fish abundance (individuals $\mathrm{m}^{-2}$ ) of 49 streams (belonging to eigth watersheds) in the Lakes Region from which 17 corresponded to Andes streams, 16 were central valley streams, and 17 were Coastal range streams. Degrees of freedom (DF), F values and P values are indicated

Análisis de varianza de datos transformados mediante logaritmo natural para analizar efecto del origen de los ríos sobre la abundancia de peces (individuos $\mathrm{m}^{-2}$ ) en 49 ríos de la Región de Los Lagos. De estos, 17 son ríos que nacen en la cordillera de los Andes, 16 se originan en el valle central y 17 en la cordillera de la Costa. Se indican grados de libertad (DF), valores de F y valores de $\mathrm{P}$

\begin{tabular}{|c|c|c|c|c|c|c|c|}
\hline & \multirow[b]{2}{*}{ df } & \multicolumn{2}{|c|}{ Ln (native fish) } & \multicolumn{2}{|c|}{ Ln (rainbow trout) } & \multicolumn{2}{|c|}{ Ln (brown trout) } \\
\hline & & $\overline{\text { F-value }}$ & $\mathrm{P}$-value & F-value & $\mathrm{P}$-value & F-value & P-value \\
\hline Intercept & 1 & 160.75 & $<0.000001$ & 226.91 & $<0.000001$ & 83.50 & $<0.000001$ \\
\hline River origin & 2 & 10.00 & 0.000249 & 12.50 & 0.000046 & 2.66 & 0.080711 \\
\hline Error & 46 & & & & & & \\
\hline
\end{tabular}




\section{TABLE 5}

Forward stepwise multiple regression analysis to predict native fish density, species richness, and rainbow and brown trout density on 34 streams $(F 4,29)$ belonging to eight watersheds of the Lakes Region. From all independent variables shown in Appendix 1 the model used a maximum of four with the best joint predictive power

Regresión múltiple por pasos hacia adelante para predecir densidad y riqueza de especies de peces nativos, densidad de trucha café y arco iris en 34 arroyos $(\mathrm{F} \mathrm{4,29)} \mathrm{pertenecientes} \mathrm{a} \mathrm{ocho} \mathrm{cuencas} \mathrm{de} \mathrm{la} \mathrm{Región} \mathrm{de} \mathrm{Los} \mathrm{Lagos.}$ De todas las variables independientes que se muestran en el Anexo 1, el modelo usó un máximo de cuatro con el mejor poder predictor conjunto

\begin{tabular}{|c|c|c|c|c|c|c|}
\hline \multirow{4}{*}{ Independent variables } & & & & \multicolumn{3}{|c|}{ Individual variable Model } \\
\hline & Dependent variables & $\mathrm{R}^{2}$ (adjusted) & Beta & $\mathrm{B}$ & $\mathrm{P}$ & $\mathrm{P}$ \\
\hline & Native fish density & & & & & \\
\hline & $\left(\right.$ ind $\mathrm{m}^{-2}$ ) & 0.66 & & & & $<0.000001$ \\
\hline Intercept & & & & -0.12 & 0.022 & \\
\hline Fine sediment on stream bed (\%) & & & 0.62 & 0.58 & $<0.001$ & \\
\hline Conductivity $\left(\mu \mathrm{mhos} \mathrm{cm}^{-1}\right)$ & & & 0.43 & 0.001 & 0.001 & \\
\hline Brown trout density (ind $\mathrm{m}^{-2}$ ) & & & -0.27 & -0.07 & 0.028 & \\
\hline \multirow[t]{3}{*}{ Pools along sampled stream (\%) } & & & 0.19 & 0.18 & 0.083 & \\
\hline & Ln (native fish specie & & & & & \\
\hline & richness) & 0.58 & & & & 0.00001 \\
\hline Intercept & & & & 7.40 & 0.372 & \\
\hline Longitude (UTM) & & & -0.30 & 0.00 & 0.037 & \\
\hline Fine sediment on stream bed $(\%)$ & & & 0.43 & 6.60 & 0.001 & \\
\hline $\mathrm{N}-\mathrm{NH} 4\left(\mu \mathrm{g} \mathrm{L}{ }^{-1}\right)$ & & & 0.30 & 0.09 & 0.012 & \\
\hline \multirow[t]{3}{*}{ Maximum temperature $\left({ }^{\circ} \mathrm{C}\right)$} & & & 0.26 & 0.30 & 0.046 & \\
\hline & Rainbow trout density & & & & & \\
\hline & (ind $\mathrm{m}^{-2}$ ) & 0.54 & & & & 0.00002 \\
\hline Intercept & & & & -17.71 & 0.009 & \\
\hline Longitude (UTM) & & & 0.33 & 0.00 & 0.012 & \\
\hline Pools along sampled stream (\%) & & & -0.41 & -6.05 & 0.002 & \\
\hline Submerged vegetation (\%) & & & -0.32 & -8.58 & 0.011 & \\
\hline \multirow[t]{2}{*}{ Water discharge $\left(\mathrm{m}^{3} \mathrm{seg}^{-1}\right)$} & & & 0.29 & 0.001 & 0.020 & \\
\hline & $\begin{array}{l}\text { Brown trout density } \\
\text { (ind } \mathrm{m}^{-2} \text { ) }\end{array}$ & 0.32 & & & & 0.004 \\
\hline Intercept & & & & 0.53 & 0.045 & \\
\hline Conductivity $\left(\mu \mathrm{mhos} \mathrm{cm}^{-1}\right)$ & & & 0.50 & 0.01 & 0.002 & \\
\hline Catchment area $\left(\mathrm{km}^{2}\right)$ & & & -0.441 & 0.000 & 0.013 & \\
\hline Vegetation cover on the stream (\%) & & & -0.259 & -0.58 & 0.133 & \\
\hline Fine sediment on stream bed (\%) & & & -0.189 & -0.67 & 0.210 & \\
\hline
\end{tabular}

Although from the study presented here, there seems to be limitations for directly inferring salmonid effects on native fish, we focused on those aspects which can explain present the distribution and abundance of salmonids, as well as those giving some indication of negative interactions among both fish groups. Specifically we are asking if native fish and salmonids show different patterns of association with geographical distribution and watershed properties.

\section{Native fish and salmonids in lakes}

Most salmon species present in lakes from souther Chile namely coho, salar and chinook should be escapees as they are only present in lakes with aquaculture activity (Fig. 2, Table 1). Population establishment or naturalization of these three species is not evident since we did not find juveniles in the streams affluent to lakes or in other connected streams. Yet the presence of adult salmon represents a 
permanent threat in these lakes and creates the opportunity to study the ecosystem resistance to invasions, particularly considering population interactions as proposed by Peterson \& Fausch (2003). Since all these lakes are by the Andes mountains, fish populations in the streams are mainly composed by rainbow and brown trout (Fig. 7) which could eventually contribute to the failure in survival of the young of the year of other salmonid species. However, a continuous propagule pressure from reproductive runs may eventually generate population establishments as it has been considered one of the important factors for successful invasions (Marchetti et al. 2004a).

In lakes, as compared to streams, we found more native fish species and larger densities (Fig. 4). Perhaps, lakes offer more refuge space and greater spatial heterogeneity. Additionally, as we only evaluated pelagic species in lakes, it is quite possible that most lakes had a larger number of native species which could not be effectively captured by our technique. Nonetheless, the presence of salmon species, especially considering their large density and biomass, represents severe threats to native fish. Since most salmon populations in these lakes are apparently landlocked (D. Soto pers. obs.), the consequences of retaining the adult salmon could seriously damage native fish, due to important predatory pressure on them. Other indirect cascade effects could be expected as these salmon could have their strongest impact on planktivorous fish such as Galaxias maculatus, an effect that has been observed in similar lakes in Argentina (Macchi et al. 1999). Such cascading effect could enhance zooplankton biomass and produce a decrease in phytoplankton biomass, which in turn could produce surprising consequences we are not yet able to foresee (Carpenter et al. 1996). An important exception to the landlocked situation mentioned before, is the chinook salmon, whose reproductive runs are already evident in some large catchments with direct ocean connection in southern Chile, such as Petrohué and Futaleufú rivers (Soto et al. 2002, Pascual 2004 in press). These massive runs bring a significant amount of marine nutrients to these pristine rivers, creating an ecosystemic connection which, though normal for the northern hemisphere (Naiman et al. 2002), did not exist here until now.
Another interesting pattern to explore further is the very low density of brown trout in the salmon farming lakes (Fig. 3) which suggests a potential negative interaction with the escaped salmon. However, since there is no information on fish composition and abundance prior to salmon farming it is not possible to distinguish this pattern from a founder effect due to differential stocking among lakes.

\section{Distribution pattern of salmonids and native fish in streams: role of watershed characteris- tics and potential stocking effects}

Clearly trout invasion in southern Chile rivers and waterways mimics in many ways the situation described for New Zealand. There, early introductions of rainbow and brown trout produced successful invasions of both species, with an apparent damaging effect on native fish (McDowall 1968, Townsend 1996, McDowall 2003). As pointed out by McDowall (2003), trout were successful in New Zealand perhaps because of their perfect fitting into the new environment. Salmonids often invade simple systems, particularly those with low fish species diversity and low or some habitat degradation (Moyle 1996, Kolar \& Lodge 2002, Peterson \& Fausch 2003). Other authors have attempted to demonstrate that watershed disturbance at the landscape level is an enhancing factor for successful introductions (Marchetti et al. 2004b). Yet, for the southern Chile case, trout dominance and success (Figs. 5 to 8 ) may not be related to watershed disturbance since most sampled watersheds are not under hydrological stress of human origin (e.g., irrigation channeling and hydroelectric dams). Even more, south of $42^{\circ} \mathrm{S}$ lat. human population densities are very low and thus little watershed disturbance can be expected. Additionally, the more detailed analysis made in the Lakes Region did not show any effect of land use (as native forest cover) on rainbow or brown trout distribution (Table 5). Particularly, brown trout resulted in a poor predictive model indicating that this species does not have major restrictions to its distribution at least related to watershed characteristics (Table 5). The distribution of rainbow trout, on the contrary, had a strong affinity with the more eastern streams indicated by the positive and significant relationship with longitude (Table 5) as well as with water 
discharge. Both conditions, better achieved in the Andean streams, can explain its higher density there (Fig. 7). Thus we could reject our original hypothesis regarding watershed disturbance as a facilitator of salmonid invasion. Recent studies have demonstrated the relevance of hydrological regime, particularly indicating that low summer flows (Fausch et al. 2001) or high variability flows (Jowett 1990, Marchetti et al. 2004a) have negative effects on rainbow trout invasion. Indeed, the separation of streams according to their origin (Fig. 1 and 2), which relevance was observed in a more detailed study in one watershed (Soto \& Arismendi 2004), allows to describe the more restricted distribution of rainbow trout (Tables 4, 5, Fig. 7). However, we cannot disregard the founder effects due to specific stocking which has been probably more intense in the lakes connected to Andean streams (Basulto 2003). For this same reason, it is more difficult to explain the dominance of rainbow trout over brown trout in the Yelcho basin and its absence in the southernmost basins where brown trout dominates (Table 2). It could be a mixture of differential stocking and stronger environmental variability which we did not measure. However, this pattern coincides with the dominance of brown trout in the most southern lakes (Fig. 3) which may reinforce the hypothesis of differential stocking favoring brown trout. This is, some lakes or watersheds were seeded with brown trout only or rainbow trout only.

Considering New Zealand as the closest comparison for invasive patterns and potential consequences, there the presence of waterfalls apparently would not allow trout to access headwaters (Townsend 2003). This does not seem to be the case in Chile as there are not apparent restrictions to trout distribution, particularly to brown trout.

Distribution of native fish in streams and potential effects of salmonids

We had two major surprises in our study; the first was the apparent absence of native fish where we expected them, this is in third to fourth order streams south from $42^{\circ} \mathrm{S}$ (Fig. 5, Table 2). Obviously the lack of information on large areas in the southern portion of the latitudinal range considered makes it more difficult to expand this finding as a generalization for southern Chile. However, our results are also supported by the review on Chilean native fish by Vila et al. (1999) whom also reported a strong decline on species southern from the Lakes Region. Additionally, other studies have suggested that the highest species richness for freshwater (Soto \& Zúñiga 1991) and terrestrial systems (Arroyo et al. 1995 ) tends to decline southern from $42^{\circ} \mathrm{S}$. Thus the decline of native fish species and density could be due to a biogeographical factor as well as to the trout effect, particularly due to the higher invasive potential when facing few native resident species (Peterson \& Fausch 2003).

Yet native fish could be using larger rivers and lakes as refuges and we do not have enough information to support this possibility. However, their absence in streams where trout are abundant (Fig. 6) suggests potential negative interactions with trout, which is reinforced by the multiple regression model where brown trout had a negative effect on native fish density (Table 5). Conversely, the absence of a "rainbow trout effect" on native fish could be due mostly to the fact that today they do not occur together (Fig. 8) as rainbow trout occupies Andean streams and native fish are more common in the central valley streams. But this in itself could be a result of negative interaction from rainbow trout.

Indeed, fish invasions have been cited as the first or second most important threat to freshwater biodiversity (Marchetti et al. 2004b) and even though we do not have causal effects, the distribution pattern of native fish may be reflecting trout effects. A negative relationship among native fish and trout abundance like the one reported here from southern Chile streams (Fig. 6) has also been described in New Zealand by Townsend \& Crowl (1991), a pattern which they called complementary, that is, we either have native fish or trout but not both. From the native fish perspective, such pattern could indicate trout predation rather than competition. Yet there is little evidence for predation on native fish by trout in Chilean streams as stomach contents of trout in streams very rarely had fish as prey item (González et al. unpublished data). This may not be surprising as native fish are not very abundant and their biomass is so much smaller than that of trout (Fig. 8) which again 
may be a result of predation. Although when trout densities are low, native fish densities never reach comparable densities (Fig. 6), not as the comparative case in New Zealand (McIntosh 2000) which suggests that trout may be using a wider ecological niche than that of native fish.

The second surprise in our study was the finding of the highest species richness and density of native fish in the Central valley streams (Fig. 7, Tables 4 and 5) whose catchments are more disturbed and are far from the original pristine conditions of southern temperate forest watersheds (Soto \& Arismendi 2004). Such pattern is reinforced by the multiple regression analysis where the best predictors of native fish density (aside from brown trout negative effect, Table 5) and species richness were inversely related to longitude. For example, the percentage of fine sediment on stream bottom which is likely to be larger in slow slope streams of the Central valley. Also native fish seem to be favored by higher conductivity and a larger percentage of pools in the streams (Table 5). Indeed, native forest cover was not a significant predictor in our model (Table 5) mostly because it was strongly correlated with longitude and with some of the other independent variables so it was not allowed in the model. But in fact we found a negative univariate correlation between native forest cover and native fish density (Pearson's $\mathrm{r}=-0.48, \mathrm{P}<0.05, \mathrm{n}=34$ ), which is exactly the opposite pattern to that expected from one of our original hypotheses. That is, native fish were not better represented in the most pristine watersheds.

Nearly 25 years ago, Campos et al. (1985) sampled some streams in the main catchments of the Lakes Region and found a similar fish distribution pattern to the one we described here, which indicates that such situation has been maintained for several decades. Indeed, Central valley streams have more nutrients, receive more agriculture fertilizers and have greater benthic production along with higher habitat heterogeneity (Soto et al. unpublished data) which may facilitate the coexistence of both trout and native fish if food is a limiting factor along with predation. Brown trout seems to be also favored by greater nutrient availability as indicated by the positive partial correlation with conductivity (Table 5).
Were native fish species ever frequent and abundant in more pristine less productive Andean streams? Were there empty niches for trout both in New Zealand and in Chile? We can hypothesize that indeed there were, at least from a body size perspective since most native species in southern Chile rivers attain a rather small maximum size (Campos et al. 1985). An exception is Percychtys trucha, "perca", which achieves maximum sizes of about $30 \mathrm{~cm}$; yet in most of the sampled streams they were practically absent. Clearly, trout size range allows them to exploit a wider diversity of food items including allocthonous prey (such as terrestrial insects). Indeed, native fish collected in our study were smaller than trout, about 45.4 $\%$ of the salmonids were larger than $10 \mathrm{~cm}$ in total length, while only $8.7 \%$ of the native fish were over that size. These were Aplochiton zebra individuals, which incidentally can use broader prey items including allochtonous items (González et al. unpublished data). Perhaps for the same reason trout biomass is always larger than native fish (Fig. 8), because they can exploit larger benthic prey organisms such as freshwater crayfish (Samasthacus spp.) and crabs (Aegla spp.) plus terrestrial productivity, hypothesis that remains to be tested. Possibly, native fish were never that abundant in Andean streams except for some species such Aplochiton zebra. In fact, very old reports cited by Basulto (2003) refer mostly to native fish in the central valley and often they refer to a poor fish fauna.

\section{Relevant themes for conservation}

Considering the rejection of the hypothesis relating watershed disturbance with the facilitation of salmonid invasion, it is clear that the most pristine habitats are more suitable for trout, specially rainbow. Since native fish are doing better in catchments with highest potential and present human perturbation, conservation measures such as National parks and reserves are not protecting native fish but paradoxically protecting trout instead, specially rainbow trout as most parks in the Lakes Region are connected to the Andes. This finding coincides with the results of an intensive analysis of fish invasions to California watersheds (Marchetti et al. 2004b) where land protection did not reduce invasive species. 
One potential approach for native fish conservation would be the re-introduction of some native species in Andean streams previous to the eradication of trout. This could provide a great opportunity to test hypotheses regarding galaxid behavior and ability to use different types of prey. However, except for first and second order streams where some control could be possible this approach is rather unfeasible in practice. The major challenge ahead is to protect or implement some conservation measures for native fish fauna in the more disturbed central valley streams.

Management tools to enhance conservation of native freshwater biodiversity should also consider that trout sport fishing is socially and economically very important in Chile, as in many other places. This apparent contradiction represents no simple challenge; since trout sport fishing is also an important driver and a strong argument for forest and aquatic ecosystem conservation in southern Chile and the Patagonian territory. Thus, we may also argue about the need for conservation of pristine forest ecosystems and waterways in order to preserve the sport fishing business. Since for most common people and for the government itself, protection of trout populations for sport fishing is a major goal, opportunities for conservation of native fish species are very restricted. Clearly, conservation is only possible when we are certain about what it is that we want to preserve, and also when we know for sure which are the major threats and impacts on native biodiversity.

Perhaps a more likely and practical conservation program could be related with the management of sport fishing. That is, using humans as a control of trout densities and distribution. In Chile, sport fishing is a very relevant and strongly growing business, which can be enhanced, contributing also to the conservation of native fish fauna. Perhaps, trout sport fishing in some central valley streams and rivers could be allowed all year round, particularly in those streams with higher native biodiversity. Such catchments usually do not attract very competitive sport fishing because they are not surrounded by scenic landscapes. However, local people could use such resource under controlled management schemes.

\section{CONCLUSIONS}

Rainbow trout and brown trout are overwhelmingly dominant over native fish accounting for more than $80 \%$ of total biomass in most third to fourth order streams from southern Chile. Meanwhile, some lakes sustain an unusually high salmon biodiversity with up to five species coexisting in a single lake, mostly due to permanent escapes. However, southern Chile catchments are still trout country as they are definitely dominant in most of them, particularly brown trout. Yet, the establishment of other salmonids is quite possible as a result of continuous escapes from aquaculture.

We can presume the negative impacts of salmon and trout on native species, based on the abundances and distribution patterns we found. And we can rely on the experimental and descriptive evidence from other countries such as the case in New Zealand (Townsend 2003) where there is a strong support for the negative impacts. Within catchments, the Central valley streams (the most disturbed catchments) with higher anthropogenic impact, were found to be refuges for native fish species. It is not clear from our results how much of the present pattern is due to historical/biogeographical factors and how much is due to trout invasion, but there is probably a mixture of both effects. The best protected aquatic environments are in the Andean areas where most national parks and reserves are located and where most of the introduced species were found. Interestingly enough, there they are protected both by the environment and by national legislation. Yet, it is unclear whether native fish species were ever successful in these pristine streams. Thus the most important mitigation and management measures should focus on the most disturbed Central valley streams where we propose a more intensive trout fishing program.

Experimental re introductions of native fish should also be attempted specially in Andes streams in order to better understand present distribution patterns and to improve conservation.

\section{ACKNOWLEDGEMENTS}

We thank M. Ruiz, C. Leal and C. Rivas for field and laboratory support. We are also grateful to $\mathrm{P}$. Araya and to B. Penaluna for valuable corrections 
to early versions of the manuscript and to E. Neira for graphical assistance. Funding for this research was provided by the Lakes Region Government (Fondo Nacional de Desarrollo Regional), by the Fisheries Research Fund (Fondo de Investigación Pesquera 2000-25) and by the FONDECYT project 1020183 . This is also a contribution of the Forest Ecosystem Services Millennium (Iniciativa Científica Milenio Chile) project.

\section{LITERATURE CITED}

ARROYO MT, L CAVIEDES, A PEÑALOZA, M RIVEROS \& AM FAGGI (1995) Relaciones fitogeográficas y patrones regionales de riqueza de especies en la flora del bosque lluvioso templado de Sudamérica. En: Armesto, Villagrán \& KalinArroyo (eds) Ecología del bosque Chileno: 71-99. Editorial Universitaria, Santiago, Chile.

BASULTO S (2003) El largo viaje de los salmones: una crónica olvidada, Propagación y cultivo de especies acuáticas en Chile. Maval Limitada Editores, Santiago, Chile. 102 pp.

CAMPOS H (1970) Introducción de especies exóticas y su relación con los peces de agua dulce de Chile. Noticiario Mensual del Museo Nacional de Historia Natural 14: 3-9.

CAMPOS H (1985) Distribution of fishes in the Andean rivers in the South of Chile. Archiv fur Hydrobiologie 104: 169-191.

CAMPOS H, J ARENAS, W STEFFEN, G AGÜERO, L VILLALOBOS \& G GONZÁLEZ (1985) Investigación de la capacidad de carga para el cultivo de salmonideos de las hoyas hidrográficas del lago Rupanco. Informe CORFO-IFOP, AP 86/ 28, Santiago, Chile. 404 pp.

CAMPOS H, G DAZAROLA, B DYER, L FUENTES, J GAVILÁN, L HUAQUÍN, G MARTÍNEZ, R MENÉNDEZ, G PEQUEÑO, F PONCE, V RUIZ, W SIELFELD, D SOTO, R VEGA \& I VILA (1998) Categorías de conservación de peces nativos de aguas continentales de Chile. Boletín del Museo Nacional de Historia Natural (Chile) 47: 101-222.

CARPENTER S, T FROST, L PERSSON, M POWER \& D SOTO (1996) Fresh water ecosystems: linkages of complexity and processes. In: Mooney HA (ed) Biodiversity and ecosystem functions: a global perspective: 299-325. John Wiley \& Sons, New York, New York, USA.

CASE TJ (1991) Invasion resistance, species build-up, and community collapse in metapopulation models with interspecies competition. Biological Journal of the Linnaean Society 42: 239-266.

DAVIDSON F \& SJ HUTCHINSON (1938) The geographic distribution and environmental limitations of the Pacific salmon (genus Oncorhynchus). Bulletin of the Bureau of Fisheries, U.S. Department of Commerce (USA) 26: 667-692.

DYER B (2000) Systematic review and biogeography of the freshwater fishes of Chile. Estudios Oceanológicos (Chile)19: 77-98.

FAUSCH KD, Y TANIGUCHI, S NAKANO, GD GROSSMAN \& CR TOWNSEND (2001) Flood disturbance regimes influence rainbow trout invasion success among five Holarctic regions. Ecological Applications 11: 1438-1455.

JOWETT IG (1990) Factors related to the distribution and abundance of brown and rainbow trout in New Zealand clear-water rivers. New Zealand Journal of Marine and Freshwater Research 24: 429-440.

LARA A, C DONOSO \& JC ARAVENA (1995) La conservación del bosque nativo en Chile: problemas y desafíos. En: Armesto, Villagran \& Kalin-Arroyo (eds) Ecología del bosque Chileno: 335-362. Editorial Universitaria, Santiago, Chile.

KOLAR CS \& DM LODGE (2000) Freshwater non indigenous species: interactions with other global changes. In: Mooney HA \& RJ Hobbs (eds) Invasive species in a changing world: 3-30. Island Press, Washington DC, Washington, USA.

KOLAR CS \& DM LODGE (2002) Ecological predictions and risk assessment for alien fishes in North America. Science 298:1233-1236.

MACCHI PJ, VE CUSSAC, MF ALONSO \& MA DENEGRI (1999) Predation relationships between introduced salmonids and the native fish fauna in lakes and reservoirs in northern Patagonia. Ecology of Freshwater Fish 8: 227-236.

MARCHETTI MP, P MOYLE \& R LEVINE (2004a). Fishes in California watersheds: characteristics of successful and failed invaders. Ecological Applications 14: 587-596.

MARCHETTI MP, P MOYLE \& R LEVINE (2004b) Fish invasions in California watersheds: testing hypotheses using landscape patterns. Ecological Applications 14: 1507-1525.

McDOWALL RM (1971) The galaxiid fishes of South America. Zoological Journal of the Linnean Society 50: 33-73.

McDOWALL RM (1968) Interactions of the native fish and alien faunas of New Zealand and the problem of fish introductions. Transactions of the American Fisheries Society 97: 1-11.

McDOWALL RM (2003) Impacts of introduced salmonids on native Galaxiids in New Zealand upland streams: a new look at an old problem. Transactions of the American Fisheries Society 132: 229-238.

McINTOSH AR (2000) Habitat and size related variations in exotic trout impacts on native galaxiid fishes in New Zealand streams. Canadian Journal of Fisheries and Aquatic Sciences 57: 2140-2151.

MOYLE P \& T LIGHT (1996) Biological invasions of fresh water: empirical rules and assembly theory. Biological Conservation 78: 149-161.

NAIMAN RJ, RE BILBY, DE SCHINDLER \& JM HEDFIELD (2002) Pacific salmon, nutrients and the dynamics of freshwater and riparian ecosystems. Ecosystems 5: 399-417.

PASCUAL M, P MACCHI, J URBANSKI, F MARCOS, $C$ RIVA ROSSI, $M$ NOVARA \& $P$ DELL'ARCIPRETE (2002) Evaluating potential effects of exotic freshwater fish from incomplete species presence-absence data. Biological Invasions 4: 101-113.

PASCUAL $M$ (in press) Introduced salmonids in Patagonia: risks, uses, and a conservation paradox. In: Berth $\mathrm{T}$ (ed) Ecological and genetic implications of aquaculture activities. Kluwer Academic Press.

PETERSON DP \& KD FAUSCH (2003) Testing population-level mechanisms of invasion by a mobile vertebrate: a simple conceptual framework for salmonids in streams. Biological Invasions 5: 239-259. 
SANZANA J (2003) Plan de manejo de la población de trucha arcoiris para la pesca deportiva en el lago Llanquihue. Tesis Ingeniería Pesquera mención Pesquerías, Facultad de Pesquerías y Oceanografía, Universidad Austral de Chile, Puerto Montt, Chile. $123 \mathrm{pp}$.

SOKAL RR \& FJ ROHLF (1995) Biometry. Third edition. WH Freeman and Company, New York, New York, USA. 887 pp.

SOTO D \& L ZÚÑ̃IGA (1991) Zooplanktonic assemblages of Chilean temperate lakes and ponds: a comparison with North-American communities. Revista Chilena de Historia Natural 64: 569-581.

SOTO D, HF JARA \& CA MORENO (2001) Escaped salmon in the Chiloé and Aysen inner seas, southern Chile: facing ecological and social conflicts. Ecological Applications 11: 1750-1762.

SOTO D, I ARISMENDI \& I SOLAR (2002) Estudio del ciclo reproductivo de las principales especies objetivo de la pesca deportiva en la X Región. Informe Proyecto FIP 2000-24. Fondo de Investigación Pesquera, Subsecretaría de Pesca, Valparaíso, Chile. 98 pp.

Associate Editor: Patricio Camus

Received November 23, 2004; accepted September 23, 2005
SOTO D \& I ARISMENDI (2004) Fauna íctica de la cuenca del río Bueno: relevancia de los afluentes en la conservación de especies nativas. In: SmithRamírez C, J Armesto \& C Valdovinos (eds) Ecología y biodiversidad de los bosques de la cordillera de la costa de Chile. Editorial Universitaria, Santiago, Chile.

TOWNSEND CR \& C CROWL (1991) Fragmented population structure in a native New Zealand fish: an effect of introduced brown trout. Oikos 61: 347354.

TOWNSEND CR (1996) Invasion biology and ecological impacts of brown trout, Salmo trutta, in New Zealand. Biological Conservation 78: 13-22.

TOWNSEND CR (2003) Individual, population, community and ecosystem consequences of a fish invader in New Zealand streams. Conservation Biology 17: 38-47.

VERGARA M (ed) (2003) La acuicultura en Chile. Ediciones Tecno-Press SA, Santiago, Chile. 335 pp.

VILA I, L FUENTES \& M CONTRERAS (1999) Peces límnicos de Chile. Boletín del Museo Nacional de Historia Natural (Chile) 48: 61-75. 


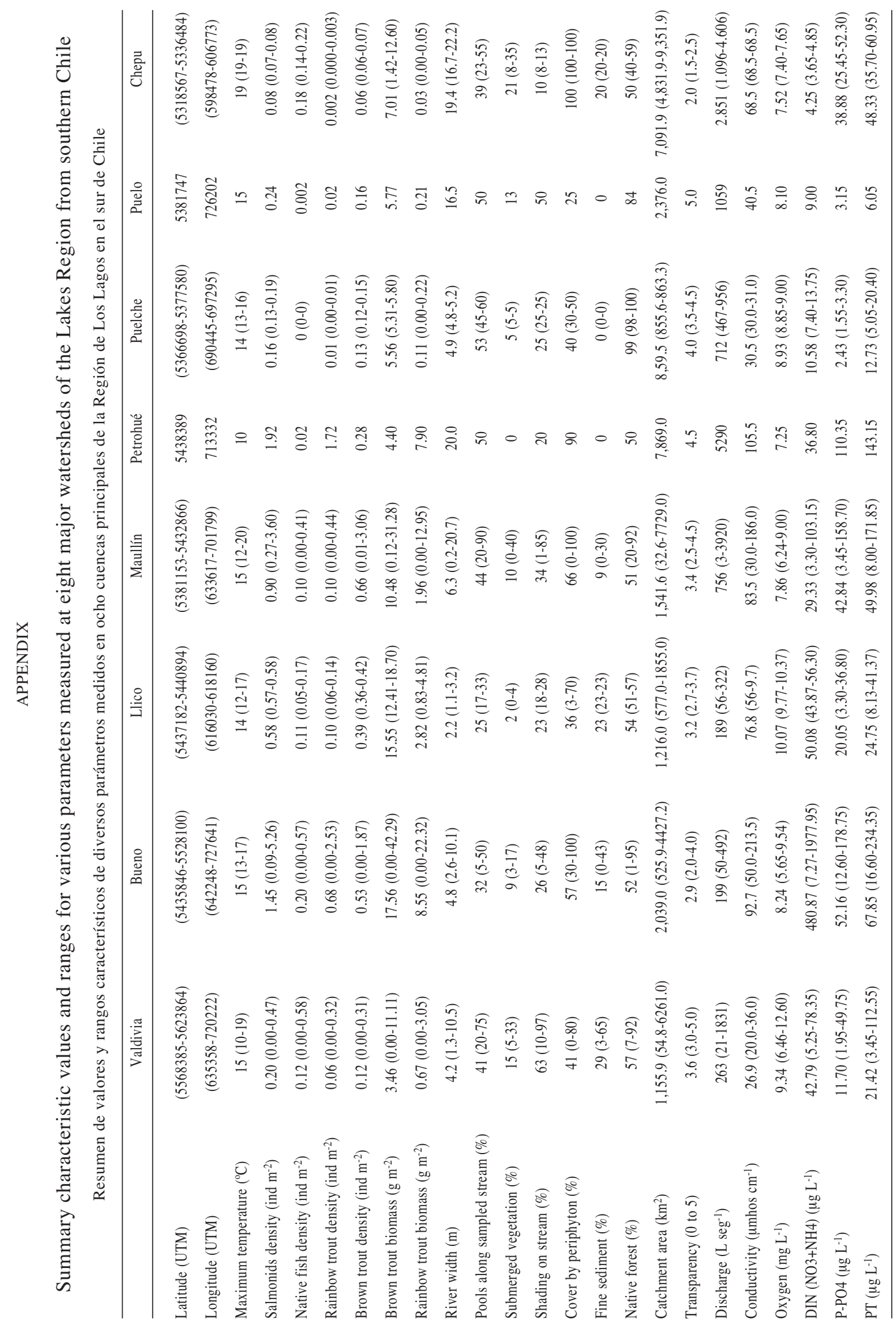

